\title{
Cash Management, Governance, and the Global Financial Crisis: Evidence From Developing Asia
}

\author{
Hasan Tekin ${ }^{1}$ (D) ${ }^{\text {, }}$, Ali Yavuz Polat ${ }^{2}$ (D) Ahmet Faruk Aysan ${ }^{3}$, Erhan Muğaloğlu ${ }^{2}$ (D) \\ ${ }^{1}$ Karabuk University, Turkey, ${ }^{2}$ Abdullah Gul University, Turkey, ${ }^{3}$ Hamad Bin Khalifa University, Qatar \\ Keywords: cash holdings, global financial crisis, governance \\ https://doi.org/10.46557/001c.27135
}

Asian Economics Letters

Vol. 2, Issue 4, 2021

We investigate how governance and the Global Financial Crisis (GFC) affect cash management. Assessing 169,916 firm-years in 26 developing Asian countries, our empirical results show that firms in good (poor) governance countries tend to hold more cash before (after) the GFC. In particular, the outcome effect of governance on cash holdings in the pre-crisis and crisis periods shifts to a substitution effect for governance in the post-crisis period in developing Asia.

\section{Introduction}

Holding cash has opportunity costs for firms. During financial crises and uncertain times, however, having a large cash balance helps firms to survive the crisis period with ease (Chen et al., 2018; Tekin \& Polat, 2020a, 2020b, 2021). In addition, cash provides growth opportunities during economic recovery periods (Song \& Lee, 2012), such that firms can seize profitable investment opportunities during times of distress. This study examines whether an agency cost explanation for cash policy is valid during and following the Global Financial Crisis (GFC). Focusing on 26 developing Asian countries with a large sample of 169,916 firm-years, we investigate the effect of governance and uncertainty on cash holdings.

The literature discusses the impact of financial crises on firm cash policy (Chen et al., 2018; Lozano \& Yaman, 2020; Tekin \& Polat, 2020b; Tran, 2020). Yet the role of governance during financial downturns is overlooked. Tekin (2020) focuses on the effect of the GFC and financial constraints on the adjustment speed of cash holdings. This author's results imply that constrained firms adjust to their target level faster and that firms in poor governance countries have lower adjustment speed compared to their peers in good governance countries.

Agency conflicts between firm owners and managers impact cash holding decisions (Jensen, 1986). Managers may have an incentive to hoard cash, since this strengthens their discretionary power (Opler et al., 1999). However, there is mixed evidence on whether an agency motive implies a higher level of cash for poorly governed firms. ${ }^{1}$ Dittmar et al. (2003) show that when legal protection is weak, firms tend to hold more cash. Seifert and Gonenc (2016) also support the agency motive from their finding that higher agency cost is associated with more cash holdings. On the other hand, Iskandar-Datta and Jia (2014) show that for places where legal protection is strong (i.e., lower agency costs), cash holdings are also higher. The literature also provides evidence that managerial entrenchment is associated with hoarding more cash (Harford et al., 2008). However, Ozkan and Ozkan (2004) find that the relationship between agency cost and cash level is non-monotonic.

During a financial crisis, since agency costs tend to be higher, holding extra cash may be even more important for firms operating in a poorly governed environment (Seifert \& Gonenc, 2016). This is due to firms in poor governance countries having greater dependence on internal funding during a crisis. The agency motive then becomes stronger when agency costs are higher in a financial crisis. Therefore, we state our research question as follows:

How is the role of governance on cash management changed by the GFC in developing Asia?

We use a sample of 26 developing Asian countries over the period 1996-2017. Firm-level data are obtained from Worldscope. Governance data specific to each country is from Kaufmann et al. (2010). We use the fixed effects method to resolve any unobserved heterogeneity problems. Our results imply that cash holdings are the outcome of governance both before and during the GFC. However, cash holdings are a substitute for governance after the GFC. Specifically, firms operating in poor governance countries in developing Asia tend to hoard more cash post-GFC.

We contribute to the literature by investigating the im-

\footnotetext{
a Corresponding author email: hasantekin@karabuk.edu.tr

1 Also, Narayan et al. (2015) show by developing country-level governance that stock returns may be predictable when governance quality is poor.
} 
pact of governance on cash policy in developing Asian markets, with the GFC as an exogenous shock. Our findings have several implications. First, managers should consider the escalating uncertainty during a crisis while making cash-related decisions. Policymakers should implement smart policies and regulations during times of exogenous shock from foreign crises like the GFC, to help firms hoard cash and strengthen their ability to survive.

This paper proceeds as follows. Section II explains the methodology and data. Section III discusses the empirical results. Finally, Section IV sets forth our conclusions.

\section{Methodology and data}

Using joint governance (GOV) by taking the annual average of six World Governance Indicators ${ }^{2}(W G I)$, we assess the role of governance on cash management in 26 developing Asian countries ${ }^{3}$ (United Nations, 2020). GOV appears to be a more appropriate variable than time-invariant variables, as it differs by country and year, capturing variations in governance and time (Tekin, 2020).

We split our sample to understand the changing impact of governance on cash across periods, as follows: entire sample (1996-2017), pre-GFC (1996-2007), GFC (2008-2009) and post-GFC (2010-2017). We also include firm-level control factors with firm and period dummies, as stated below:

$$
\begin{aligned}
C A S H_{i j, t}= & \beta_{0}+\beta_{1} G O V_{j, t}+\beta_{2} D I V_{i, t} \\
& +\beta_{3} S I Z E_{i, t}+\beta_{4} M B R_{i, t}+\beta_{5} I N V_{i, t} \\
& +\beta_{6} L E V_{i, t}+\beta_{7} N W C_{i, t}+\beta_{8} C F A_{i, t} \\
& +\beta_{9} R \& D_{i, t}+\alpha_{i j} F_{i}+\alpha_{t} Y_{t}+\varepsilon_{i j, t}
\end{aligned}
$$

where, $\mathrm{CASH}_{i j, t}$ is cash and short-term investments to total assets for firm $i$ and market $j$ at time $t ; G O V_{j, t}$ is joint governance (annual average score of the mean of six governance indicators); $D I V_{i, t}$ is dividends (cash dividends / total assets); $S I Z E_{i, t}$ is firm size (log of total assets); $M B R_{i, t}$ is market-to-book ratio ([total assets - book value of equity + market value of equity] / total assets); $I N V_{i, t}$ is investments (capital expenditures / total assets); $L E V_{i, t}$ is leverage (total debt / total assets); $N W C_{i, t}$ is net working capital ([current assets - current liabilities - cash and short-term investments] / total assets); $C F A_{i, t}$ is cash flow ([pre-tax income + depreciation - cash and short-term investments] / total assets); $R \& D_{i, t}$ is an $\mathrm{R} \& \mathrm{D}$ dummy ( $\mathrm{R} \& \mathrm{D}$ expenses / total assets); $F_{i}$ and $Y_{t}$ are firm and year fixed effects, respectively, controlling for unobservable factors that impact the cash ratio; and $\varepsilon_{i j, t}$ is the error term.

We retrieve firm-level data from Worldscope and governance variables from Kaufmann et al. (2010) for 26 developing Asian markets. Since publication of WGI begins in 1996, we determine the sample period as 1996-2017. Excluding financial and utility firms (Lozano \& Yaman, 2020), our sam-

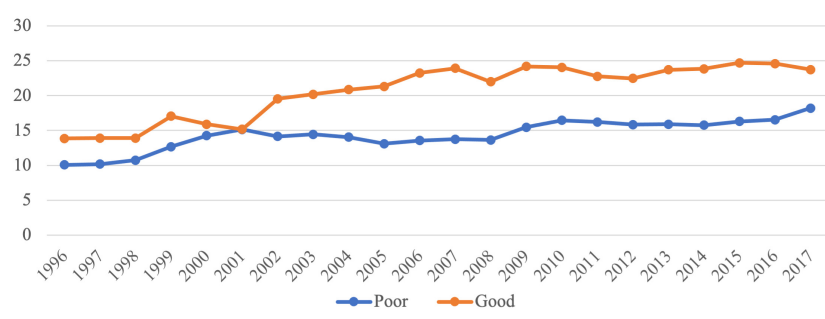

Figure 1. Trends on cash holdings across poor- and good-governance in developing Asia

This figure shows how cash holdings change over time across poor- and goodgovernance in developing Asia.

Source: Kaufmann et al. (2010) and Worldscope.

ple includes 169,916 firm-years from a sample of 14,430 non-financial Asian firms. We winsorize all firm-level variables at 1\% and 99\% (Tekin, 2020). In Table A.2, we introduce (i) mean of cash and governance across countries in Panel A, (ii) descriptive statistics in Panel B, and (iii) correlation matrix in Panel $\mathrm{C}$, reporting the variance inflation factor $\left(\mathrm{VIF}^{4}\right)$.

\section{Empirical results}

Given the occurrence of financial crises, the importance of cash management to firms' trade and operations arises due to increasing costs for external financing. Thus, cash management becomes crucial to firm survival during exogenous shocks. We introduce cash mean by annually splitting the sample above- and below-mean considering governance level, as shown in Figure 1 and Table 1. As previous research (Tekin, 2020) confirms, firms in good governance countries have higher cash levels than those in poor governance countries over the study period, as shown in Figure 1.

In particular, firms in good governance countries increased their cash levels about 6\% more in pre-GFC compared to the GFC period, whereas those in poor governance countries raised their cash stocks nearly $3 \%$ higher after the GFC compared to pre-GFC. In Table 1, we examine statistical differences in the mean of cash pre-crisis and postcrisis, across firms in poor and good governance countries. Overall, firms in good governance countries have about $7 \%$ higher cash over time, and all firms increase their cash stocks nearly $3 \%$ from pre- to post-crisis.

We analyze the association between governance and cash holdings in Table 2 . We run our analysis by splitting the data as follows: pre-GFC (1996-2007), GFC (2008-2009), and post-GFC (2010-2017) in columns 1 to 3, respectively. In column 1, we indicate that firms in good governance countries increase their cash levels more, with the coefficient of 0.001 at the $1 \%$ level of significance for the pre-

\footnotetext{
2 Worldwide Governance Indicators are as follows: control of corruption, rule of law, regulatory quality, voice and accountability, government effectiveness, and political stability.

3 The list of 26 countries is presented in Panel A of Table A.2.

4 We check VIF values to determine whether our data suffer from multicollinearity. As VIF values are lower than 5 (Tekin \& Polat, $2020 \mathrm{~b}$ ), our data confront no multicollinearity problem.
} 
Table 1. Mean of cash across poor- and good-governance from pre- to post-crisis

\begin{tabular}{lcccc}
\hline & Pre-GFC (1996-2007) & Post-GFC (2010-2017) & post - pre & $t$-stat. \\
\hline Good governance & $(1)$ & $(2)$ & (3) = (2) - (1) & $(4)$ \\
Poor governance & 0.208 & 0.238 & 0.030 & $11.67^{* * *}$ \\
Good vs. Poor & 0.136 & 0.163 & 0.027 & $32.83^{* * *}$ \\
$t$-stat. & 0.072 & 0.075 & & \\
& $41.78^{* * *}$ & $50.46^{* * *}$ & & \\
\hline
\end{tabular}

This table compares the mean of cash across firms in poor- and good-governance countries from pre-GFC to post-GFC period. The number of observations is 56,851 and 90,838 (7,967 and 15,194$)$ firm-years for firms in poor (good) governance countries in the pre-GFC and post-GFC periods, respectively. Lastly **** represents the statistical significance at the $1 \%$ level.

GFC period, in line with the literature (Iskandar-Datta \& Jia, 2014). In column 2, similar to the pre-GFC period, the positive effect of governance on cash is equally significant during the GFC (the coefficient is 0.002 and significant at the $1 \%$ level). However, the picture changes ${ }^{5}$ post-GFC, as shown in column 3. In particular, firms in poor governance countries raise more cash post-crisis (the coefficient is -0.002 at $1 \%$ ). Thus, cash holding is a substitute for governance in developing Asia (Dittmar et al., 2003; Seifert \& Gonenc, 2016). In sum, firms in poor governance Asian countries tend to increase cash holdings, as Tekin (2020) recently confirms using international evidence. Regarding robustness concerns, we rerun the analyses in Table 2 by employing net cash, calculated as cash and short-term investments to net assets (total assets minus short-term investments). These results are qualitatively similar to our main results. Therefore, the role of governance on cash does not depend on the measure of cash.

In addition, all firm-level control factors, excluding cash flow, are negatively related to cash holding over the entire period, but the picture differs in the subperiods. Specifically, firm size, market-to-book ratio, and R\&D investment have no impact on cash pre-GFC but are negatively associated with cash post-GFC. These results demonstrate that agency, precautionary, and transaction motives of cash vary with the existence of exogenous shocks.

We test potential endogeneity between cash and governance by employing a panel reverse causality test. In Appendix tables, Table A.1, shows that while the coefficient of lagged GOV is 0.000 and is significant at the 1\% level (column 1), the coefficient of lagged cash is insignificant (column 2). This suggests that cash holdings have no impact on governance, implying that our results do not suffer from endogeneity problems (Adjaoud \& Ben-Amar, 2010).

\section{Conclusion}

We assess how governance affects cash management in developing Asia before, during, and after the GFC. Employing fixed effects, our findings show that firms in poor gov- ernance developing Asian markets increase their cash levels more post-GFC. Namely, cash holdings have a substitution effect for governance post-GFC. On the other hand, the outcome role of governance strengthens from the pre-GFC to the GFC period. We contribute to the literature by extending the assessment of governance and cash management in light of the GFC. Our findings hold several implications. First, managers should make their cash decisions taking into account possible circumstances of market turmoil. Investors should consider the governance level of countries in determining where and which firms to invest in. Policymakers may strategically restructure policies and regulations associated with hoarding cash instead of disgorging cash, so as not to hurt firms in times of exogenous shock, such as the GFC. Practitioners and researchers should consider institutional settings and uncertainties and their impact on cash management in developing Asia. These results are especially applicable to the post-COVID-19 world, where unexpected shocks are becoming more common.

Submitted: March 07, 2021 AEDT, Accepted: April 27, 2021 AEDT

\footnotetext{
5 We compare the coefficients of governance (GOV) in columns 1 and 3 by employing the seemingly unrelated estimation code in Stata. According to this check, the coefficient of GOV in the pre-GFC period (0.001, significant at the $1 \%$ level) is significantly different from that in the post-GFC period (-0.002, significant at the $1 \%$ level).
} 
Table 2. Governance and cash management in developing Asia

\begin{tabular}{|c|c|c|c|}
\hline & \multicolumn{3}{|c|}{ Dependent variable: CASH } \\
\hline & Pre-GFC (1996-2007) & GFC (2008-2009) & Post-GFC (2010-2017) \\
\hline Variables & (1) & (2) & (3) \\
\hline \multirow[t]{2}{*}{ GOV } & $0.001^{* * *}$ & $0.002^{* *}$ & $-0.002^{* * *}$ \\
\hline & $(0.000)$ & (0.001) & $(0.000)$ \\
\hline \multicolumn{4}{|l|}{ Controls } \\
\hline \multirow[t]{2}{*}{ DIV } & $-0.129^{* * *}$ & $-0.158^{* * *}$ & $-0.214^{* * *}$ \\
\hline & (0.010) & (0.015) & $(0.012)$ \\
\hline \multirow[t]{2}{*}{ SIZE } & $-0.009^{* * *}$ & $-0.007^{* * *}$ & $-0.011^{* * *}$ \\
\hline & $(0.001)$ & $(0.001)$ & $(0.001)$ \\
\hline \multirow[t]{2}{*}{ MBR } & 0.000 & 0.005 & 0.000 \\
\hline & $(0.002)$ & $(0.004)$ & $(0.002)$ \\
\hline \multirow[t]{2}{*}{ INV } & $-0.063^{*}$ & -0.030 & $-0.069^{* * *}$ \\
\hline & $(0.035)$ & $(0.047)$ & $(0.027)$ \\
\hline \multirow[t]{2}{*}{ LEV } & $-0.146^{* * *}$ & $-0.271^{* * *}$ & $-0.308^{* * *}$ \\
\hline & $(0.006)$ & (0.009) & $(0.006)$ \\
\hline \multirow[t]{2}{*}{ NWC } & $-0.157^{* * *}$ & $-0.149^{* * *}$ & $-0.183^{* * *}$ \\
\hline & $(0.006)$ & $(0.008)$ & $(0.005)$ \\
\hline \multirow[t]{2}{*}{ CFA } & $0.147^{* * *}$ & $0.139^{* *}$ & $0.166^{* * *}$ \\
\hline & $(0.008)$ & $(0.012)$ & $(0.008)$ \\
\hline \multirow[t]{2}{*}{$R \& D$} & $0.019^{* * *}$ & 0.014 & $0.020^{* * *}$ \\
\hline & $(0.003)$ & $(0.003)$ & $(0.002)$ \\
\hline \multirow[t]{2}{*}{ Constant } & $0.247^{* * *}$ & $0.223^{* * *}$ & $0.423^{* * *}$ \\
\hline & $(0.017)$ & (0.031) & $(0.015)$ \\
\hline Adjusted $\mathrm{R}^{2}$ & 0.659 & 0.822 & 0.729 \\
\hline Observations & 58,655 & 20,686 & 90,575 \\
\hline Firms & 9,608 & 10,788 & 14,372 \\
\hline
\end{tabular}

This table presents the role of governance on cash holdings across the pre-GFC, GFC, and post-GFC periods. CASH is the cash and short-term investments to total assets. Variables are defined in Section II. Country and industry dummies are included. Standard errors are given by parentheses (). Finally, *******and * imply statistical significance at the $1 \%, 5 \%$ and $10 \%$ levels, respectively. 


\section{REFERENCES}

Adjaoud, F., \& Ben-Amar, W. (2010). Corporate governance and dividend policy: Shareholders' protection or expropriation? Journal of Business Finance \& Accounting, 37(5-6), 648-667. https://doi.o rg/10.1111/j.1468-5957.2010.02192.x

Chen, H.-C., Chou, R. K., \& Lu, C.-L. (2018). Saving for a rainy day: Evidence from the 2000 dot-com crash and the 2008 credit crisis. Journal of Corporate Finance, 48 , 680-699. https://doi.org/10.1016/j.jcorpfin.2017.12.0 $\underline{25}$

Dittmar, A., Mahrt-Smith, J., \& Servaes, H. (2003). International corporate governance and corporate cash holdings. Journal of Financial and Quantitative Analysis, 38(1), 111-133. https://doi.org/10.2307/412 $\underline{6766}$

Harford, J., Mansi, S. A., \& Maxwell, W. F. (2008). Corporate governance and firm cash holdings in the US. Journal of Financial Economics, 87(3), 535-555. htt ps://doi.org/10.1016/j.jfineco.2007.04.002

Iskandar-Datta, M. E., \& Jia, Y. (2014). Investor protection and corporate cash holdings around the world: New evidence. Review of Quantitative Finance and Accounting, 43(2), 245-273. https://doi.org/10.10 07/s11156-013-0371-y

Jensen, M. C. (1986). Agency costs of free cash flow, corporate finance, and takeovers. The American Economic Review, 76(2), 323-329.

Kaufmann, D., Kraay, A., \& Mastruzzi, M. (2010). The worldwide governance indicators: Methodology and analytical issues. World Bank Policy Research Working Paper, 5430.

Lozano, M. B., \& Yaman, S. (2020). The European financial crisis and firms' cash holding policy: An analysis of the precautionary motive. Global Policy, 11(S1), 84-94. https://doi.org/10.1111/1758-5899.127 $\underline{68}$

Narayan, P. K., Sharma, S. S., \& Thuraisamy, K. S. (2015). Can governance quality predict stock market returns? New global evidence. Pacific-Basin Finance Journal, 35, 367-380. https://doi.org/10.1016/j.pacfi $\underline{\text { n.2015.02.007 }}$
Opler, T., Pinkowitz, L., Stulz, R., \& Williamson, R. (1999). The determinants and implications of corporate cash holdings. Journal of Financial Economics, 52(1), 3-46. https://doi.org/10.1016/s030 4-405x(99)00003-3

Ozkan, A., \& Ozkan, N. (2004). Corporate cash holdings: An empirical investigation of UK companies. Journal of Banking \& Finance, 28(9), 2103-2134. https://doi.or g/10.1016/j.jbankfin.2003.08.003

Seifert, B., \& Gonenc, H. (2016). Creditor rights, country governance, and corporate cash holdings. Journal of International Financial Management \& Accounting, 27(1), 65-90. https://doi.org/10.1111/jifm.12033

Song, K. R., \& Lee, Y. (2012). Long-term effects of a financial crisis: Evidence from cash holdings of East Asian firms. Journal of Financial and Quantitative Analysis, 47(3), 617-641. https://doi.org/10.1017/s002 $\underline{2109012000142}$

Tekin, H. (2020). How optimal cash changed by the global financial crisis? A multi-country analysis. Economics and Business Letters, 9(2), 114-123. http s://doi.org/10.17811/ebl.9.2.2020.114-123

Tekin, H., \& Polat, A. Y. (2020a). Do market differences matter on dividend policy? Borsa Istanbul Review, 21(2), 197-208. https://doi.org/10.1016/j.bir.2020.1 $\underline{0.009}$

Tekin, H., \& Polat, A. Y. (2020b). Is saving vital? Evidence from the financial crisis. Economics and Business Letters, 9(2), 124-134. https://doi.org/10.178 11/ebl.9.2.2020.124-134

Tekin, H., \& Polat, A. Y. (2021). Adjustment speed of debt maturity: Evidence from financial crises in East Asia. Bulletin of Monetary Economics and Banking, 24(1), 71-92.

Tran, Q. T. (2020). Financial crisis, shareholder protection and cash holdings. Research in International Business and Finance, 52(101131). http s://doi.org/10.1016/i.ribaf.2019.101131

United Nations. (2020). World Economic Situation Prospects, Statistical Annex. https://doi.org/10.18356/ ee1a3197-en 


\section{Appendix}

Table A.1. Causality test of the relation between cash and governance

\begin{tabular}{lll}
\hline & Dependent variable: CASH & Dependent variable: GOV \\
\hline Lagged GOV & $(1)$ & $(2)$ \\
& $0.000^{* * *}$ & $0.819^{* * *}$ \\
Lagged CASH & $(0.000)$ & $(0.003)$ \\
& $0.712^{* * *}$ & 0.015 \\
Firm controls & $(0.004)$ & $(0.026)$ \\
Observations & Yes & Yes \\
Firms & 160,252 & 160,252 \\
\hline
\end{tabular}

This table presents the causality relationship between governance and cash holdings. Variables are defined in Section II. Country and industry dummies are included. Standard errors are given by parentheses (). Lastly, ${ }^{* * *}$ implies statistical significance at the $1 \%$ level. 
Table A.2. Sample composition, descriptive statistics, and correlation matrix

\begin{tabular}{|c|c|c|c|c|c|c|c|c|c|c|}
\hline \multicolumn{11}{|c|}{ Panel A. Sample composition and means of cash and governance } \\
\hline & Bahrain & Bangladesh & China & Hong-Kong & India & Indonesia & Iraq & Jordan & Kazakhstar & \\
\hline CASH & \%18.1 & \%11.2 & \%19.9 & $\% 23.6$ & $\% 7.5$ & \%12.1 & \%23.8 & \%10.1 & $\% 8.9$ & \\
\hline \multirow[t]{2}{*}{ GOV } & $\% 52.5$ & $\% 21.6$ & $\% 36.4$ & $\% 86.9$ & $\% 43.9$ & $\% 35$ & $\% 8.8$ & $\% 50$ & $\% 33.7$ & \\
\hline & Kuwait & Lebanon & Malaysia & Oman & Pakistan & Philippines & Qatar & Russia & S. Arabia & \\
\hline CASH & \%16.4 & $\% 9.4$ & \%14.6 & \%11.7 & $\% 8.7$ & \%14.9 & $\% 16.4$ & \%9.8 & $\% 10.5$ & \\
\hline \multirow[t]{2}{*}{ GOV } & $\% 53.2$ & $\% 30.3$ & $\% 61$ & $\% 58.8$ & $\% 21.1$ & $\% 40.9$ & $\% 67.1$ & $\% 27$ & $\% 43.6$ & \\
\hline & Singapore & S. Korea & Sri Lanka & Syria & Taiwan & Thailand & Turkey & Vietnam & WHOLE & \\
\hline $\mathrm{CASH}$ & \%19.9 & $\% 16.6$ & $\% 8.8$ & $\% 10.9$ & $\% 22$ & $\% 11.4$ & $\% 9.7$ & $\% 12.9$ & $\% 16.2$ & \\
\hline GOV & $\% 87.6$ & $\% 72.8$ & $\% 43.1$ & $\% 10.5$ & $\% 78.3$ & $\% 47.6$ & $\% 48.1$ & $\% 36.5$ & $\% 57.1$ & \\
\hline \multicolumn{11}{|c|}{ Panel B. Descriptive statistics } \\
\hline & CASH & GOV & DIV & SIZE & $M B R$ & INV & LEV & NWC & CFA & $R \& D$ \\
\hline Mean & 0.162 & 57.093 & 0.054 & 15.059 & 0.606 & 0.005 & 0.239 & 0.024 & 0.010 & 0.336 \\
\hline Median & 0.111 & 50.512 & 0.031 & 14.648 & 0.506 & 0.000 & 0.208 & 0.029 & 0.019 & 0.000 \\
\hline SD & 0.162 & 20.529 & 0.069 & 2.799 & 0.847 & 0.027 & 0.208 & 0.214 & 0.152 & 0.472 \\
\hline Min & 0.000 & 1.849 & 0.000 & 4.762 & 0.088 & 0.000 & 0.000 & -0.649 & -0.823 & 0.000 \\
\hline Max & 0.940 & 90.101 & 0.897 & 26.427 & 20.876 & 0.477 & 1.000 & 0.863 & 0.933 & 1.000 \\
\hline \multicolumn{11}{|c|}{ Panel C. Correlation matrix } \\
\hline & CASH & GOV & DIV & SIZE & MBR & INV & LEV & NWC & CFA & VIF \\
\hline GOV & $0.191^{a}$ & & & & & & & & & 1.12 \\
\hline DIV & $-0.079^{a}$ & $-0.073^{a}$ & & & & & & & & 1.03 \\
\hline SIZE & $-0.102^{a}$ & $-0.049^{a}$ & $0.051^{a}$ & & & & & & & 1.14 \\
\hline MBR & $-0.118^{a}$ & $-0.104^{a}$ & $-0.005^{a}$ & $-0.074^{a}$ & & & & & & 1.25 \\
\hline INV & $-0.058^{a}$ & $-0.107^{a}$ & $-0.049^{a}$ & $-0.060^{a}$ & $0.255^{a}$ & & & & & 1.42 \\
\hline LEV & $-0.400^{a}$ & $-0.120^{a}$ & $0.063^{a}$ & $0.149^{a}$ & $0.306^{a}$ & $0.004^{a}$ & & & & 1.09 \\
\hline NWC & $-0.014^{a}$ & $0.038^{a}$ & $-0.069^{a}$ & $-0.111^{a}$ & $-0.261^{a}$ & $-0.002^{\mathrm{a}}$ & $-0.423^{a}$ & & & 1.31 \\
\hline CFA & $0.155^{a}$ & $-0.104^{a}$ & $0.091^{a}$ & $0.076^{a}$ & $-0.172^{\mathrm{a}}$ & $0.022^{\mathrm{a}}$ & $-0.316^{a}$ & $0.284^{a}$ & & 1.22 \\
\hline$R D D$ & $0.141^{a}$ & $0.231^{a}$ & $0.007^{a}$ & $0.229^{a}$ & $-0.096^{a}$ & $-0.069^{a}$ & $-0.095^{a}$ & $0.076^{a}$ & $0.021^{a}$ & 1.15 \\
\hline
\end{tabular}

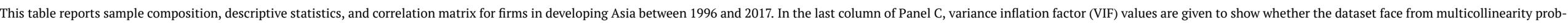
lem. Since VIF values are smaller than 5 , there is not any multicollinearity problem. ${ }^{a}$ implies statistical significance at $1 \%$, 